\title{
THE SEARCH FOR COMMON INTERNATIONAL DENOMINATORS IN ACCOUNTING AND REPORTING
}

\author{
by Henk Volten
}

1 The preparation of financial statements and the application of accounting standards are the prime responsibility of the management of an enterprise. Users of financial statements have a legitimate interest in the principles governing their preparation. The setting of accounting standards is not wholly within the scope of the accountancy profession.

2 Where accountancy bodies issue standards, the first objective must be to acquire acceptance and observance by the industrial and business community, stock exchanges and if necessary governments. Without that acceptance, it is unreasonable to require members in public practice to enforce their observance on the business community by, for example, reference to non-compliance in the audit report.

3 I am aware of the fact that many accountancy bodies prefer society to leave standard setting in their care. It is also common knowledge that these stand. ard setting bodies are in trouble from the moment that the business community does not accept their pronouncements. It always affects their authority and in some cases they have perished as a result of the opposition.

\section{Tripartite Study Group}

4 In Holland, the standard setting process is not viewed as the exclusive respon sibility of the Nederlands Instituut van Registeraccountants (NIVRA). Accounting principles are developed in a so-called Tripartite Study Group (TSG), which comprises representatives from the Confederation of Enterprises, the trade unions and NIVRA (which prepares most of the original drafts through its Accounting Principles Committee).

5 The involvement of employers in attempts to improve financial reporting has a long history. In 1955 the Dutch employers' unions established a mixed committee, mainly consisting of executive managers. The findings of that committee constitute the first set of recommendations on the annual accounts, including some essential ones regarding accounting principles.

When the TSG was established in the early 70 s. the inclusion of employees seemed a logical step in view of their interest in and reliance on the com. pany's affairs.

Many colleagues abroad would not envisage a similar step in their country. Some may have changed their mind when they recently noted how the trade unions have established themselves as a most influential group in the UN Group of Experts on transnational corporations. The interest of trade unions in financial reporting is apparent also from a report "Trade union requirements for accounting and publication by undertakings and groups of companies", published June 1977 by the International Confederation of Free Trade Unions. 
7 The Dutch TSG in its composition is probably unique in the world. Started as an experiment in social relations, it works quite well if one accepts that it needs time and the occasional compromise to get the agreement of all parties represented in the Group. The big advantage, of course, lies in the pos. sibilities for acceptance, observance and enforcement of recommendations which are endorsed by corporate management and labour.

8 The TSG follows closely the developments in the Common Market concern ing the harmonization of company law.

The Group participates in the formulation of comments on IASC exposure drafts and the international standards are also reviewed in the light of Dutch practice at the request of NIVRA. In 1977, TSG issued a statement which in. dicated general acceptance of IAS $1 \cdot 6$.

\section{Common Market}

9 In the field of harmonization of company law, the European Commission has sought the assistance of the accountancy bodies of Common Market coun. tries. The European Study Group of Accountants meets monthly in Brussels. Its main task is to comment on EEC draft directives but in some cases, at the request of the Commission, it also prepares original documents.

10 Under the terms of the Treaty of Rome, member countries must incorporate the provisions of directives which have been approved by the Council of Ministers, in their national laws and, if necessary, change national law accordingly.

In their international activities NIVRA and several other European bodies give the highest priority to Brussels, in view of the impact upon national law.

11 The European Study Group has almost always presented a unanimous view, a prerequisite for influencing a body like the Commission. Of special importance is the draft Fourth Directive which deals with "the presentation and content of the annual accounts and report, methods of valuation, and publication of those documents". The accountancy profession has been instrumental in acquiring the inclusion of fundamental clauses such as (1) the overriding objective of a true and fair view, (2) the admissibility of current value accounting, and (3) the basic considerations of consistency, going concern, accrual and prudence.

12 It should be noted that international harmonization meets more constraints in Europe than it does world wide. At a global scale, the profession is largely homogeneous: there is a similarity owing to common (Anglo Saxon) origins. In accounting this includes Holland, but generally in Europe it meets with a continental tradition of rather detailed legal regulation of accounting treatment, format of financial statements and contents of the audit report.

\section{International Accounting Standards Committee}

13 Modern economic expansion transcends national boundaries. Certainly, in my country, not many enterprises can confine their business dealings and trade arrangements to the geographical area of Holland.

Because it interprets and expresses the consequenses of economic influences, 
accounting is vitally concerned. In the wake of international commerce there is a need for the formulation of uniform auditing and accounting standards to which independent accountants in all countries can adhere.

14 One of the first to voice this need publicly was a distinguished Dutch colleague. Jacob Kraayenhof, president of the Seventh International Congress in Amsterdam. On several occasions between 1957 and 1962, on both sides of the Atlantic, he called upon the leading accountancy bodies to develop jointly "a broad set of accepted principles and their meaning". I like to put this on record since IASC was not founded until well into the 70 s and present day students might tend to overlook the influence of earlier pioneers.

15 I should also like to emphasize that Kraayenhofs plea contained the two most significant conditions for a successful operation: that the leading bodies should participate and that the objective should be to agree upon basic standards.

In both respects IASC qualifies. In IASC, the accountancy profession has a vehicle in the search for common denominators in accounting and reporting. How should it proceed?

\section{Objectives of standard setting}

16 Amongst the leading accountancy bodies one may expect a reasonable amount of common opinion and, when that is absent, (a) the ability of discussion partners to grasp quickly the essentials of an opposite view, and (b) a preparedness to reconsider a position when faced with a strong majority. These circumstances provide a firm basis for reaching agreement (including agreement about the range of options and agreement to differ).

17 The purpose should be to formulate standards which reflect a common level of practice in countries with fully developed accountancy professions. The standards will assist the development of the profession in other countries, and in this respect they are not minimum standards.

18 On the other hand, they cannot be maximum standards either. Accounting theory and concepts often indicate solutions which in practice cannot, at the time, be implemented. In those instances, developed practice - and not a theoretical concept must determine the contents of accounting standards, lest the business community reject them.

19 Indeed, the expected degree of compliance must be the final test for approval of a standard.

Generally, IASC has been aware of this, and in two recent cases (financial statements of banks, and the treatment of price fluctuation) it has contemplated a preliminary discussion of an exposure draft with interested partners.

It seems to me that it would enhance the status of international accounting standards and facilitate enforcement, if IASC sought the involvement, and possibly active participation, of interested parties outside the profession on a more regular basis. I especially refer to the international trade union or. ganization.

20 As to conceptualism, it is a disturbing thought that occasionally accountancy 
theorists invent concepts which, the more they are declared logical and the deeper they are worshipped by accountants, the more vigorously they are rejected by the business community. The concept of general price level accounting is an illustration, and in my opinion the concept of the temporal principle in foreign currency translation will also prove to be one. Perhaps the application of common sense should receive more emphasis.

21 The same may hold for the search of the objectives of financial statements which is gradually becoming embedded in yet another conceptual frame. work. I subscribe to drs. I. Kleerekoper's view expressed at the Accountants. dag 1976 of NIVRA that in the past decades "no definitive system of norms has been derived from all the examination of the purposes and objectives of the annual accounts and related questions. Even if such a system was produced this would be so remote from every day practice that it could not be implemented."

22 Insofar as the research for conceptual objectives is related to the different needs of users of financial statements it would be more practical, and would certainly provide a constructive contribution to the debate, to indicate the area of disclosure of nonfinancial information: labour and employment, new products, investment programme, geographical breakdown of production and turnover, organizational structure, principal shareholders, affiliation and emoluments of directors, environmental measures, social report, etc.

23 Legal authorities (e.g. Article 41 of the EEC draft Fourth Directive contains several disclosure requirements), but also OECD and the UN Center on trans. national corporations appear to provide the main thrust towards nonfinan cial data. An aloof attitude of accountants may ultimately have an adverse effect.

The determination of data not traditionally associated with financial reporting but which should be disclosed, forms a challenge for all standard setting bodies.

24 Finally I invite attention to the dangers and damage of a procrustean approach in accounting standards.

One objective is that the application of the standards makes a comparison between enterprises possible. On the other hand, the standards must rec. ognize the need for differing treatment of differing factual circumstances. As SEC Chief Accountant John C. Burton once put it: "The rules must not be so rigid as to force unlike entities into the same reporting."

25 The EEC draft Fourth Directive contains a fairly stricty format for annual accounts, - though far less rigid, due to the European Study Group of Accountants, than it originally was.

Both the Dutch TSG and, in most cases. IASC have allowed flexibility without providing an unjustifiable wide range of options.

26 It makes it predictably easier to reach agreement when international harmonization is directed towards basic standards, and this supports uniformity.

But IASC has also experienced basic disagreement, especially on the treatment of price fluctuation (IAS 6) and of foreign currency translation (E 11). At the request of the convenor of the Conference I have included some remarks about these subjects in appendices.

In the face of massive non-compliance if it gave preferences to a specific 
treatment. IASC has wisely followed the path of allowing extreme options with full disclosure.

27 I submit that a solution to many issues can be found in the introduction of disclosure requirements. This by the way also provides an opportunity to satisfy the information needs of different users of financial statements. In allowing disclosure solutions, two basic demands should be met, both included in IAS 1:

(a) substance over form: transactions and other events should be presented in accordance with their substance and financial reality and not merely with their legal form.

(b) inappropriate treatment of items in balance sheets or income statements is not rectified either by disclosure of accounting policies used or by notes or by explanatory material.

April 1978

\section{Appendix 1: The treatment of changing prices (inflation accounting)}

The Conference authorities have requested critical consideration of the specific issue of the treatment of changing prices, and I do this with pleasure.

As far back as the Twenties a theory of business economics was developed in the Netherlands (mainly by Professor Limperg), with the aim of ensuring the continuity of the enterprise. The two principal conclusions were:

- that cost had to be calculated on the basis of the replacement value of the means of production used, and

- that profit had to be determined on current value basis.

In order to give a true and fair view of invested equity, it followed almost naturally that balance sheet valuations also had to be on the same basis. A number of Dutch enterprises adopted replacement value accounting in the course of time. Both NIVRA and TSG have indicated a preference for a current value approach. A TSG pronouncement is expected soon, laying down as a minimum requirement that historical cost based accounts shall contain supplementary information concerning current value data.

Internationally, the debate between accounting for general versus specific price changes is over for practical purposes. The current value approach has won.

I always like to quote para. 755 of the Sandilands Report in full:

Current Cost Accounting is similar to the system which is regarded as best practice in Holland. It is compatible also with the current draft of the EEC Fourth Directive.

Around the world many countries are headed towards a current value method. Pioneer documents have been issued in Germany (a recommendation entitled "Accounting for Capital Maintenance in the Measurement of Company Profits", issued in October 1975) and Australia (a preliminary exposure draft "A method of current value accounting", December 1975). In the United Kingdom, Sandilands has been followed first by Morpeth (CCA, ED 18) and then by the Hyde proposals, and in the United States a SEC requirement of replacement cost data has induced the AICPA to publish a proposed statement of position on presenta- 
tion and disclosure of supplementary current value information (January 27, 1978).

General agreement about the direction to take, however, leaves standardized implementation a long way off.

As a first step towards standardization I suggest a requirement that financial statements should show the following data:

a) current value income

b) realized holding gains, i.e. the excess of replacement cost over historical cost of goods sold in the reporting period

c) historical cost income

d) unrealized holding gains of the period

e) total increase of equity as recorded.

The elements are interrelated:

- current value income plus realized holding gains is historical cost income

- historical cost income plus unrealized holding gains is total increase of equity

- current value income plus all holding gains is total increase of equity.

These data should be given in an interrelated form (for example in a supplementary statement starting either from current value or from historical cost income).

The data indicated here already provide bases for decisions: for management in proposing dividends to shareholders as well as for trade unions in their bargaining with the company. It seems to me that a further step towards standardization warrants agreement in two areas closely related to the implementation of current values

- back log depreciation

- the effect of the financial structure.

Australia and Germany respectively have indicated solutions here.

The Australian draft is the only one which deals with the theoretically needed catch up of depreciation for prior periods. It discusses three possible treatments and settles for a charge to retained earnings.

As to the effect of the financial structure of an enterprise, the German recommendation results in the determination of that part of historical cost income which is considered fictitious income. In other words, realized holding gains are indicated, but only to the extent that inventories and fixed assets are financed by equity capital. In the recent Hyde proposals "gearing" expresses a similar idea. Note: In Dutch practice, current value based statements have recognized neither back $\log$ depreciation nor the company's financial structure. A possible rea. son for this is that in many cases the effects on income offset one another: back $\log$ depreciation leads to a charge to income, and the separate treat. ment of loan-financed revaluations adds to income.

I have indicated a variety of relevant data in connection with accounting for changing prices.

1 Historical cost and current value income

2 Realized and unrealized holding gains

3 The extent to which holding gains are self-financed, and

4 Back log depreciation. 
These data are useful in forming a judgement on a company's affairs and prospects. Further relevant information could concern

5 Holding gains or revaluation reserve, subject to future taxation

6 The application of a general index to equity, to indicate the erosion of the company's capital.

In my opinion, it is not necessary to develop one standardized method of valuation. Any method will do, whereby the different data mentioned before are represented, either in the basic accounts or supplementary, and preferably in an orderly (reconciled) way.

It follows that the accountancy profession needs not bother to harmonize internationally the general valuation method, but should concern itself primarily with reaching agreement upon the list of data which all financial statements must supply.

\section{Appendix 2: A note on foreign currency translation}

Conceptual evidence has led the FASB to choose the temporial method as the $\mathrm{fa}$ vourite son of the historical rate methods. A great majority of companies outside the USA uses the closing (or current) rate method. IASC has accommodated both views in Exposure Draft 11: Accounting for Foreign Transactions and Translation of Foreign Financial Statements.

I know of no better and concise way to make my position clear than by quoting, slightly adapted, para's 10 through 14 of the Australian proposed statement "Translation of Amounts in Foreign Currencies" (September, 1973).

"The object of translating the accounts of a Dutch company's foreign-based operation is to enable their incorporation into the company's accounts or group accounts at a Dutch guilders equivalent that fairly presents, from the Dutch viewpoint, the results and financial position of that foreign-based operation in a way which is helpful to the users of the Dutch financial statements.

The use of historic rates for this purpose rests on the view that foreign-based operations are simply distant extensions of the home company, thus requiring accounts of such operations to be maintained in terms of Dutch guilders. All transactions are therefore translated at historic rates. As a result the Dutch accounts reflect the historical cost of those transactions as if they had taken place in Holland, using Dutch guilders. However, the above view ignores the underlying fact that the foreign-based operation is a separate business unit, and its transactions are carried out in a foreign currency. That foreign currency is the measuring unit of the operation's financial position and performance, and its financial statements are expressed in that foreign currency in accord. ance with the laws of the country of domicile.

The problem in translating these statements into another measuring unit (the Dutch guilder) is that the values of these units relative to each other may change with the passage of time. The current rate at the end of the period is the relevant one to the users of the financial statements of a Dutch company, thereby justifying its use for this purpose. The basis of accounting (for example, historical cost) adopted in the foreign-currency statements remains unaffected, 
and the results and position of the operation, having been fairly reported (and audited), are then translated in a simple, convenient, and relevant manner."

Indeed, the closing rate method is simple, convenient and relevant. On the other hand, it has been called - in Financial Executive of January, 1978 - the failure of FASB 8 and the temporal method "to cope with apparent inconsistencies with some common sense notions".

The source of the quote is important here. I reiterate that a gap between accounting concepts and business pragmatism will invite noncompliance and might ultimately harm the accountancy profession.

One final issue should be mentioned: the treatment of translation gains and losses.

Under the temporal method as endorsed by the FASB, basically all translation differences go to the income statement. This creates what is sometimes referred to as a "yo-yo effect" on reported net income, - the reader of the financial statements has no firm basis on which to judge the trend of the company's results of operations.

This, however, is not a basic condition of the temporal method, as is shown by the IASC draft which permits reporting differences arising under the temporal method as changes in shareholders' interests or deferring them.

april 1978 